15 Goodman R, Meltzer H, Bailey V. The strengths and difficulties questionnaire: a pilot study on the validity of the self-report version. Eur Child Adol Psych 1998; 7: 125-30.

16 DfE. Statistical First Release SFR 18/2011. Department for Education, 2011.

17 Brunner M, Nagy G, Wilhelm O. A tutorial on hierarchically structured constructs. J Pers 2012; 80: 796-846.

18 Muthén LK, Muthén BO. Mplus User's Guide. (7th edn). Muthén \& Muthén, 2012.

19 Finney SJ, DiStefano C. Non-normal and categorical data in structural equation modeling. In Structural Equation Modeling: A Second Course (eds GR Hancock, RO Mueller): 269-314. Information Age, 2006.

$20 \mathrm{Hu}$ L-T, Bentler PM. Cutoff criteria for fit indexes in covariance structure analysis: conventional criteria versus new alternatives. Struct Equ Modeling 1999; 6: 1-55.

21 Yung Y-F, Thissen D, McLeod L. On the relationship between the higher-orde factor model and the hierarchical factor model. Psychometrika 1999; 64: 113-28

22 Chen $\mathrm{H}$, Cohen $\mathrm{P}$, Chen S. How big is a big odds ratio? Interpreting the magnitudes of odds ratios in epidemiological studies. Commun Stat Simul Comput 2010; 39: 860-4

23 Masten AS, Roisman GI, Long JD, Burt KB, Obradovic J, Riley JR, et al. Developmental cascades: linking academic achievement and externalizing and internalizing symptoms over 20 years. Dev Psych 2005; 41: 733-46.
24 Moffitt TE, Caspi A, Dickson N, Silva P, Stanton W. Childhood-onset versus adolescent-onset antisocial conduct problems in males: natural history from ages 3 to 18 years. Dev Psychopathol 2009; 8: 399.

25 Nolen-Hoeksema S, Girgus JS. The emergence of gender differences in depression during adolescence. Psychol Bull 1994; 115: 424-43.

26 Goodman A, Lamping DL, Ploubidis GB. When to use broader internalising and externalising subscales instead of the hypothesised five subscales on the strengths and difficulties questionnaire (SDQ): data from British parents, teachers and children. J Abnormal Child Psych 2010; 38: 1179-91.

27 De Los Reyes A. Strategic objectives for improving understanding of informant discrepancies in developmental psychopathology research. Dev Psychopathol 2013; 25: 669-82.

28 Lahey BB, Van Hulle CA, Singh AL, Waldman ID, Rathouz PJ. Higher-order genetic and environmental structure of prevalent forms of child and adolescent psychopathology. Arch Gen Psychiatry 2011; 68: 181-9.

29 Cross-Disorder Group of the Psychiatric Genomics Consortium. Identification of risk loci with shared effects on five major psychiatric disorders: a genome-wide analysis. Lancet 2013; 381: 1371-9.

30 Fernandez J. Immune diosrders. In Merck Manual Online (eds RS Porter, JL Kaplan): Merck Sharp \& Dohme, 2014.

31 Moffitt TE, Harrington HL, Caspi A, Kim-Cohen J, Goldberg D, Gregory AM, et al. Depression and generalised anxiety disorder: cumulative and sequential co-morbidity in a birth cohort followed to age 32. Arch Gen Psychiatry 2007: 64: $651-60$.

\title{
Did you mean to be so rude? Meaningless comments and the Mental State Examination
}

\author{
Suhanthini Farrell
}

Appearance and behaviour: Middle-aged woman, morbidly obese, frizzy greying hair, dressed inappropriately.

'There,' she said, pointing with a trembling finger to her copy of an old clinic letter, as she blinked back tears. 'Would you come back if someone wrote that about you?'

Probably not. Like her, I would have been horrified and humiliated, and hidden away from mental health services until it was almost too late. The fact that it was technically true made no difference.

I reflected on what that sentence really added to her clinical care. Her age was clear from her date of birth; her weight, if relevant, should have been recorded as part of her medical history. The frizziness or otherwise of a person's hair has no influence on my prescribing practice, and the comment on the 'inappropriateness' of her dress was sufficiently vague to add nothing to my understanding while being really quite offensive.

Psychiatric records are filled with comments and descriptions just like this. I began to wonder why. Of course there are times when a person's appearance will be clinically relevant and require comment; just as a cardiologist would note a patient's xanthelasma, or a neurologist their shuffling gait. But how often do we actually think about how useful the information is? Or do we just describe the patient's appearance by rote because we were told, as medical students, that it's just what psychiatrists do?

Surely the Mental State Examination should be just that - an examination that critically evaluates the evidence in front of us, using our clinical skills and experience, ultimately adding value to an assessment. A collection of random, casual comments adds nothing, as well as (in our modern world of transparency and copied clinic letters) having the potential to cause harm.

Perhaps we could start by taking a few seconds before we put pen to paper - or mouth to voice recorder - and think about what we actually need to say. 